\title{
Maintaining International Peace and Security: Reflections on Peace-Support Operations in Africa
}

\author{
DR THEO NEETHLING \\ Centre for Military Studies, University of Stellenbosch
}

\begin{abstract}
The shift from a bipolar to a multipolar and multi-faceted world has reduced the risk of conventional inter-state wars, but has been the cause of several intra-state armed conflicts with an even higher risk of regional instability. Such conflicts and the resurgence of a global activism have produced a dramatic growth in peacekeeping requirements since the end of the previous decade. The international response, mainly through the United Nations (UN), has been to promote preventive diplomacy and, in a number of cases, to conduct peace-support operations.
\end{abstract}

In brief, this paper points out that each UN peace-support operation places an extremely high premium on UN administration, organisation, coordination and resources. To this end, a multiplicity of contributions from various role-players is needed. It also points out that peace-support operations require significant commitments on the part of participating states, specifically the willingness to accept financial costs and fatalities in the interest of promoting international and regional stability. This is especially true in the case of African peacekeeping.

This paper, furthermore, underscores the fact that the undertaking of peace-support operations in Africa is by no means a simple and easy task. The nature of peacekeeping missions in certain African countries have, in fact, resulted in an increasing reluctance on the part of the major powers and some of the other traditional troop-contributing nations to deploy on 
African soil. It concludes that the real impact of the post-Cold War era is that the burden of resolving African conflicts rests more and more on Africans. African countries and organisations are accordingly compelled to take measures and develop strategies to address the peacekeeping requirements on the continent.

\section{INTRODUCTION}

Although the formation of the UN was intended to deal with inter-state warfare, it is being required more and more often to respond to intra-state instability and conflict. In those conflicts the main aim, increasingly, is the destruction not just of armed forces, but of civilians and even entire ethnic groups. Conflict in the African environment poses a major challenge to UN efforts designed to ensure global peace, prosperity and human rights for all. In 1996 alone, 14 of the 53 countries of Africa were afflicted with armed conflicts, accounting for more than half of all war-related deaths worldwide and resulting in 8 million refugees and displaced persons. The consequences of those conflicts have seriously undermined Africa's efforts to ensure long-term stability, prosperity and peace for its people.'

In a broader context the end of the Cold War has not resulted in worldwide peace and stability. The shift from a bipolar to a multipolar and multifaceted world has in fact reduced the risk of conventional inter-state wars, but has been the cause of several intra-state armed conflicts with an even higher risk of regional instability. Such conflicts and the resurgence of a global activism have produced a dramatic growth in peacekeeping requirements since the end of the previous decade. The international response, mainly through the $\mathrm{UN}$, has been to promote preventive diplomacy and, in a number of cases, to conduct peace-support operations. In this regard, UN operations swiftly moved from traditional military peacekeeping tasks to multidimensional operations in "failed" and disintegrating states.

Research in the field of peacekeeping has focused on a wide range of issues and has attracted a large academic following. Much of this research 
has concentrated on what is theoretically desirable, whereas the political and practical implications have often been neglected. This has promoted high expectations of the peacekeeping role of the UN that cannot necessarily be met.

In the following analysis, an overview is given of the authority and competence to establish peace-support operations, as well as an outline of the reasons for involvement in peace-support operations. This is followed by an analysis of completed UN peace-support operations in Africa with special reference to the factual situation regarding the strength, fatalities and expenditures of each operation. The multiplicity of inputs needed to conduct peace-support operations is subsequently addressed by focusing on the UN experience in Liberia. Finally, an attempt is made to provide greater clarity with regard to the direction of future UN peacekeeping in the African context.

This article is not an attempt to sketch a gloomy picture of international peace-support operations in Africa and further afield. Nor is it an effort to allude to the shortcomings of the African continent in the international community. Rather, it is an attempt to assess the challenges and perils associated with peace-support operations in general and Africa in particular. In a similar vein, it is an effort to reflect upon the magnitude and implications of UN peace-support operations with specific reference to the African continent.

\section{AUTHORITY AND COMPETENCE TO ESTABLISH UN PEACE- SUPPORT OPERATIONS}

The first of the objectives of the UN listed in its Charter is "to maintain international peace and security, and to this end: to take effective collective measures for the prevention and removal of threats to the peace, and for the suppression of acts of aggression or other breaches of the peace, and to bring about by peaceful means, and in conformity with the principles of justice and international law, adjustment or settlement of international disputes or situations which might lead to a breach of the peace". Concrete 
measures to achieve this purpose that are to be taken by the UN Security Council are set out in Chapters VI and VII of the UN Charter. ${ }^{2}$

Chapter VI provides that international disputes "likely to endanger the maintenance of international peace and security" can be brought to the attention of the Security Council or the General Assembly. If the Security Council determines that a threat to the peace, breach of the peace or act of aggression exists, the Council may use the broad powers given to it in Chapter VII of the Charter. Should the Security Council regard it necessary, it may take, under Article 42, "action by air, sea and land forces as may be necessary to maintain or restore international peace and security". Article 43 , however, requires unanimity within the Council before action is taken. Provision is also made in the Charter for the UN and regional and subregional organisations to form and maintain partnerships and act decisively and expeditiously in devising approaches to crisis prevention, management and resolution. Chapter VIII of the UN Charter covers this in article 53 which states that "[t]he Security Council shall, where appropriate, utilise such regional arrangements or agencies for enforcement action under its authority". 3

The UN does not have an army to perform peace-support actions. For each peace-support mission, member states voluntarily provide troops and equipment for which they are compensated from a special peacekeeping budget. Police officers, election observers, human rights monitors and other civilians sometimes work alongside military personnel in peace-support operations. ${ }^{4}$

Because the UN is the source of authority for types of peace-support operations, its set of terms and definitions is of importance. An Agenda for Peace has sought to identify a new approach to UN peacekeeping. It suggested that it was no longer appropriate to consider peacekeeping in isolation, and presented the concepts of preventive diplomacy, peacemaking, peacekeeping and post-conflict peacebuilding as a range of options to be considered in the context of peace-support activities. None of these concepts were really new, but were presented as a range of options to be considered in the context of peace-support activities. In the report, the 
terms "preventive diplomacy", "peacemaking", "peacekeeping" and "post conflict peacebuilding" were defined as follows: ${ }^{5}$

- Preventive diplomacy is action to prevent disputes from arising between parties, to prevent existing disputes from escalating into conflicts and to limit the spread of the latter when they occur.

- Peacemaking is action to bring hostile parties to agreement, essentially through such peaceful means as those foreseen in Chapter VI of the Charter of the UN.

- Peacekeeping is the development of a UN presence in the field, hitherto with the consent of all parties concerned, normally involving UN military and/or police personnel and frequently civilians as well. Peacekeeping is also a technique that expands the possibilities for both the prevention of conflict and the making of peace.

- Post-conflict peacebuilding is action to identify and support structures that will tend to strengthen and solidify peace in order to avoid a relapse into conflict.

It is noteworthy that "peacemaking" refers to the use of diplomatic means to persuade parties in conflict to cease hostilities and to negotiate a peaceful settlement of their dispute. As with "preventive diplomacy", or "preventive action", as it is currently referred to by the Secretary-General of the UN, the UN can play a role only if the parties to the dispute agree that it should do so. Peacemaking thus excludes the use of force against one of the parties to enforce an end to hostilities, an activity that in UN parlance is referred to as "peace enforcement". 6 The notion "peace-support operations" is now widely used in doctrine, for example, in documents of the North Atlantic Treaty Organisation (NATO), to cover all "peacekeeping", "peace enforcement" and related operations. 


\section{MOTIVES FOR INVOLVEMENT IN PEACE-SUPPORT OPERATIONS}

There may be more than one reason for countries to become motivated to participate in multinational peace-support operations. One reason may be that peacekeeping is viewed by some governments as a means of keeping the armed forces gainfully occupied. Other reasons may relate to international influence and obligations as peacekeeping is sometimes literally viewed as the epitome of international morality.

Until recently, some of the more traditional peacekeeping participants, such as Canada and the Scandinavian countries, equated participation in peacekeeping with "good international citizenship". However, indications are that altruistic considerations are on the wane and stand to be replaced by considerations of national prestige and own interest - particularly since many newcomers were added to the number of peacekeeping nations since the late $1980 \mathrm{~s}^{7}$

Speaking on behalf of the United Kingdom (UK), former Secretary of State for Defence, Mr. Malcolm Rifkind, outlined the (then) British perspective as follows: ${ }^{8}$

"We need to consider the criteria against which the UK should judge whether or not to become involved in a peacekeeping or peacemaking mission. The first criterion must be the national interest... It is difficult to predict where conflicts may lead, and wider strategic and security interests, not always defence related, come into play."

Other factors considered by a country like the UK relate to its position and commitments as a permanent member of the UN Security Council. In the case of the United States (US), US Presidential Decision Directive 25 clearly declares the following: ${ }^{9}$

"When deciding whether to support a particular UN peace operation, the United States will insist that fundamental questions be asked before 
new obligations are undertaken. These include an assessment of the threat to international peace and security, a determination that the peace operation serves US interests..."

These considerations aside, the political will of national governments to contribute material and human resources to peace-support operations depends in no small terms on the effectiveness of the UN itself as reflected in its ability to conduct peace-support operations successfully. This would seem to be especially relevant in the case of African peace-support operations.

\section{PROFILE OF COMPLETED PEACE-SUPPORT OPERATIONS IN AFRICA $^{10}$}

An investigation of completed UN peace-support operations indicates that from the total of 32 operations, twelve were set up in Africa, seven in the Americas, five in Asia, five in the Middle East and three in Europe. In Africa, the following missions were established (in alphabetical order): ${ }^{11}$

\begin{tabular}{|c|c|}
\hline UN Angola Verification Mission I (UNAVEM I) & January 1989 to June 1991 \\
\hline UN Angola Verification Mission II (UNAVEM II) & June 1991 to February 1995 \\
\hline UN Angola Verification Mission III (UNAVEM III) & February 1995 to June 1997 \\
\hline $\begin{array}{l}\text { UN Aouzou Strip Observer Group for Chad/Libya } \\
\text { (UNASOG) }\end{array}$ & May to June 1994 \\
\hline UN Assistance Mission for Rwanda (UNAMIR) & October 1993 to March 1996 \\
\hline UN Observer Mission in Liberia (UNOMIL) & September 1993 to September 1997 \\
\hline $\begin{array}{l}\text { UN Observer Mission for } \\
\text { (UNOMUR) }\end{array}$ & June 1993 to September 1994 \\
\hline UN Operation in the Congo (ONUC) & July 1960 to June 1964 \\
\hline UN Operations in Mozambique (UNOMOZ) & December 1992 to December 1994 \\
\hline UN Operations in Somalia I (UNOSOM I) & April 1992 to March 1993 \\
\hline UN Operations in Somalia II (UNOSOM II) & March 1993 to March 1995 \\
\hline $\begin{array}{l}\text { UN Transition Assistance Group (UNTAG) in } \\
\text { Namibia }\end{array}$ & April 1989 to March 1990 \\
\hline
\end{tabular}




\section{Expenditures, human resources and fatalities}

The above-mentioned UN peace-support operations have taken a toll as regards expenditures, the utilisation of human resources and, in some cases, fatalities, as indicated hereafter: ${ }^{12}$

\section{- UN Angola Verification Mission I (UNAVEM I) ${ }^{13}$}

\begin{tabular}{|l|l|}
\hline Expenditures: & $\$ 16404200$ net \\
\hline Strength: & $\begin{array}{l}70 \text { military observers, supported by internationally and locally recruited } \\
\text { civilian staff }\end{array}$ \\
\hline Fatalities: & None \\
\hline
\end{tabular}

- UN Angola Verification Mission II (UNAVEM II) ${ }^{14}$

\begin{tabular}{|l|l|}
\hline Expenditures: & $\$ 175802600$ net \\
\hline Strength: & $\begin{array}{l}350 \text { military observers, 126 police monitors; there were also some } 80 \\
\text { international civilian staff and 155 local staff and up to 400 electoral } \\
\text { observers }\end{array}$ \\
\hline Fatalities: & $\begin{array}{l}5 \text { (2 military observers, 1 other military personnel, 1 police observer and } \\
1 \text { international civilian staff })\end{array}$ \\
\hline
\end{tabular}

\section{- UN Angola Verification Mission III (UNAVEM III) ${ }^{15}$}

\begin{tabular}{|l|l|}
\hline Expenditures: & from inception to 30 June 1997: \$887 196 700 \\
\hline Strength: & $\begin{array}{l}\text { as of 30 June 1997: mission total of 4 220 military personnel, composed } \\
\text { of 283 military observers, 3 649 troops and 288 civilian personnel }\end{array}$ \\
\hline Fatalities: & 32 \\
\hline
\end{tabular}

- UN Aouzou Strip Observer Group for Chad/Libya (UNASOG) ${ }^{16}$

\begin{tabular}{|l|l|}
\hline Expenditures: & $\$ 67471$ \\
\hline Strength: & 9 military observers and 6 international civilian staff \\
\hline Fatalities: & None \\
\hline
\end{tabular}




\section{- UN Assistance Mission for Rwanda (UNAMIR) ${ }^{17}$}

\begin{tabular}{|l|l|}
\hline Expenditures: & from inception to 19 April 1996: \$437 430 100 net \\
\hline Strength: & $\begin{array}{l}\text { some } 5500 \text { military personnel, including approximately } 5200 \text { troops and } \\
\text { military support personnel and } 320 \text { military observers, as well as } 120 \\
\text { civilian police personnel; there was also a provision for internationally } \\
\text { and locally recruited civilian staff }\end{array}$ \\
\hline Fatalities: & $26(3$ military observers, 22 other military personnel and 1 civilian police) \\
\hline
\end{tabular}

\section{- UN Observer Mission in Liberia (UNOMIL) ${ }^{18}$}

\begin{tabular}{|l|l|}
\hline Expenditures: & $\$ 81488699$ net \\
\hline Strength: & See details below \\
\hline Fatalities: & None \\
\hline
\end{tabular}

\section{- UN Observer Mission for Uganda/Rwanda (UNOMUR) ${ }^{19}$}

\begin{tabular}{|l|l|}
\hline Expenditures: & $\$ 2298500$ net \\
\hline Strength: & $\begin{array}{l}81 \text { military observers, supported by internationally and locally recruited } \\
\text { civilian staff }\end{array}$ \\
\hline Fatalities: & None \\
\hline
\end{tabular}

- UN Operation in the Congo $(\mathrm{ONUC})^{20}$

\begin{tabular}{|l|l|}
\hline Expenditures: & $\$ 400130793$ \\
\hline Strength: & $\begin{array}{l}19828 \text { military personnel, supported by internationally and locally } \\
\text { recruited civilian staff }\end{array}$ \\
\hline Fatalities: & $250(245$ military personnel and 5 international civilian staff $)$ \\
\hline
\end{tabular}

\section{- UN Operations in Mozambique (UNOMOZ) ${ }^{21}$}

\begin{tabular}{|l|l|}
\hline Expenditures: & \$471 199200 \\
\hline Strength: & $\begin{array}{l}\text { 6625 troops and military support personnel, 354 military observers and 1 } \\
144 \text { civilian police; there were also some 355 international staff and 506 } \\
\text { local staff; in addition, during the polling, ONUMOZ deployed } \\
\text { approximately 900 electoral observers }\end{array}$ \\
\hline Fatalities: & $\begin{array}{l}\text { 24 (21 military personnel, 2 civilian police and 1 international civilian } \\
\text { staff) }\end{array}$ \\
\hline
\end{tabular}




\section{- UN Operations in Somalia I (UNOSOM I) ${ }^{22}$}

\begin{tabular}{|l|l|}
\hline Expenditures: & $\$ 42931700$ net \\
\hline Strength: & $\begin{array}{l}50 \text { military observers, } 3500 \text { security personnel, up to } 719 \text { logistic support } \\
\text { personnel; there were also some 200 international civilian staff }\end{array}$ \\
\hline Fatalities: & 8 (military personnel) \\
\hline
\end{tabular}

- UN Operations in Somalia II (UNOSOM II) ${ }^{23}$

\begin{tabular}{|l|l|}
\hline Expenditures: & $\$ 1643485500$ net \\
\hline Strength: & $\begin{array}{l}\text { Approximately } 28000 \text { military and police personnel; there was also a } \\
\text { provision for some 2 } 800 \text { internationally and locally recruited staff }\end{array}$ \\
\hline Fatalities: & $\begin{array}{l}147(143 \text { military personnel, 3 international civilian staff and } 1 \text { local } \\
\text { staff) }\end{array}$ \\
\hline
\end{tabular}

- UN Transition Assistance Group in Namibia (UNTAG) ${ }^{24}$

\begin{tabular}{|l|l|}
\hline Expenditures: & $\$ 368584324$ \\
\hline Strength: & $\begin{array}{l}\text { At maximum deployment, UNTAG's overall strength was approximately } \\
8000 \text { consisting of some 4 500 military personnel, 1 500 police officials } \\
\text { and 2 } 000 \text { civilians }\end{array}$ \\
\hline Fatalities: & $\begin{array}{l}19 \text { (11 military personnel, 4 civilian police, 3 international civilian staff } \\
\text { and 1 local staff })\end{array}$ \\
\hline
\end{tabular}

\section{Appraisal and evaluation}

Against this background 5 of the $12 \mathrm{UN}$ peace missions in Africa have resulted in fatalities exceeding 20 lives on the part of UN peacekeepers. In two of the five cases fatalities of more than 140 were reported. Expenditures varied from \$2 298500 (UNOMUR) to \$1 643485500 (UNOSOM II). In comparison with other international peace-support operations the situation is as follows:

- In peace-support operations in the Americas none of the seven UN peace missions has resulted in fatalities of more than 10 deaths on the 
part of UN peacekeepers. Expenditures varied from \$88 573157 in the case of the UN Observer Group in Central America (ONUCA) between 1989 and $1992^{25}$ to $\$ 315794700$ in respect of the UN Mission in Haiti (UNMIH) between 1993 and $1996 .^{26}$

- In Asia, only one of the five peace-support operations resulted in fatalities, namely the UN Transitional Authority in Cambodia (UNTAC) between 1992 and 1993, where the loss of 78 lives was reported. Substantially high expenditures were likewise only compelled in the case of the UNTAC. It amounted to \$1 620963300 - almost equal to that in Somalia. ${ }^{27}$

- In Europe, only the Yugoslav crisis compelled the UN to establish peace missions. In Croatia, the UN Confidence Restoration Operation (UNCRO) between 1995 and 1996 resulted in 16 fatalities. ${ }^{28}$ In the case of the UN Protection Force in the former Yugoslavia (UNPROFOR) between 1992 and 1995, a loss of 167 lives was reported. Estimated expenditures in respect of the latter amounted to an enormous $\$ 4616725556$. $^{29}$

- In Middle East peace-support operations, two of the five operations resulted in substantial or serious fatalities, ${ }^{30}$ namely a loss of 107 lives pertaining to the First UN Emergency Force in the Middle East (UNEF I) between 1956 and $1967^{31}$ and 55 as regards the Second UN Emergency Force in the Middle East (UNEFII) between 1973 and $1997 .^{32}$ Expenditures varied from $\$ 177895000$ in the case of the UN Iran-Iraq Military Observer Group (UNIIMOG) between 1988 and $1991^{33}$ to $\$ 444487000$ in respect of UNEFII. ${ }^{34}$

The UN Department of Public Information rightly states that peacesupport operations "is dangerous business" and refers to the fact that 1500 UN peace-keepers have died in the performance of their duties since $1945 .^{35}$ Accordingly, participation in peace-support operations requires significant commitments on the part of participating states, specifically the willingness to accept financial costs and fatalities in the interest of promoting international and regional stability. 
High fatalities can therefore have long term effects on a nation's willingness to participate in future operations or even operations in a certain part of the world. In fact, with the rise in fatalities sustained by UN missions in the 1990s worldwide, a number of countries have increasingly become reluctant to commit their forces. For any democratic government it is extremely difficult to justify fatalities in peace-support operations where clear and compelling interests cannot be identified. In addition, the costs of such operations and the massive logistic commitment with regard to long distance operations - as in the case of Africa - are key factors in the decision-making processes of responsible governments.

The second most costly and most numerously staffed international peace-support operation to date was that of Somalia. Only UNPROFOR, the UN mission in the former Yugoslavia, involved more costs and personnel on the part of the UN. The Somali experience, in particular, has provided important lessons for all potential African peace-support operations. Major operational challenges in Somalia were posed by problems relating to geography, transportation and the complex political system. In general, Africa's artificial borders, combined with decades of colonial manipulation and economic exploitation, almost guarantee that the continent's circumstances provide serious and expensive challenges for peacekeepers. Likewise, the lack of infrastructural development and the political intractability of most African conflicts inevitably cause the financial costs of peace-support operations to remain relatively high. ${ }^{36}$

Generally speaking, African peace-support operations seem to be an even greater challenge than those in most other parts of the world are. The "messy" nature of peacekeeping missions in Somalia, Rwanda, Mozambique and Angola have, in fact, resulted in an increasing reluctance on the part of the major powers and the traditional troop-contributing nations to deploy on African soil. ${ }^{37}$ In Rwanda, for example, a three-year UN 'peacekeeping' operation failed to halt ethnic genocide that resulted in between 500000 and one million deaths. In spite of the UN's efforts to restore peace, a silent genocide continued in Rwanda. ${ }^{38}$ 
In view of the above, cognisance must be taken of the fact that Europe is by no means an island of peace. The conflicts in the former Yugoslavia and the Caucasus region, the tensions in Cyprus and the fragile peace process in the Middle East are important security concerns in the European community. All this is happening on Europe's doorstep. And in Russia, Ukraine and other eastern European countries, democracy and market economies are still by no means so firmly established as to be irreversible. There remain a number of unsolved and deeply-rooted tensions and

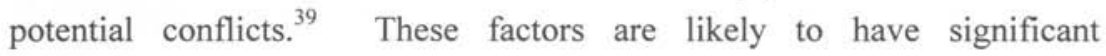
implications for the commitment or willingness of European countries which form a most important part of the resource base of the UN - to take part in multinational efforts to restore stability and security on the African continent in the short to medium-term.

In the case of the US it would seem that Africa's physical remoteness from the core of US interests has not encouraged a proper focus on the challenges or the means to address African conflicts. For example, in 1995 the US was celebrating the Dayton Accord that brought an end to the destructive war in the former Yugoslavia; a conflict that recorded the deaths of 250000 people. In more or less the same period, between 1992 and 1994, at least 500000 people died in Angola - twice the number in half the time - and no less were massacred in a few months during 1994, in Rwanda. However, the US did not address these conflicts with the same apparent focus and energy. ${ }^{40}$ At the same time, it must be remembered that the US vividly recalls the peace-support operation in Somalia in 1993 where 18 American soldiers were killed and a US soldier was being dragged through the streets of Mogadishu. Since then, Washington has been reluctant to commit US troops to African missions. In the light of the preceding, the American as well as the French and British views on African peacekeeping requirements are today strongly oriented to pursue an African approach in resolving African conflicts. ${ }^{41}$ 


\section{THE MAGNITUDE OF CONDUCTING PEACE-SUPPORT OPERATIONS}

Traditionally, there are five sources from which the UN derives logistic support: the UN held infrastructure; logistic units provided by member states; commercial sources; member states via 'stand alone national agreements' and support provided independently by member states for specific operations. $^{42}$

Peace-support missions used to take three to six months to be fully deployed. With the demand for quick and complex peacekeeping following the end of the Cold War, member states and the Secretary-General have been seeking ways to reduce deployment time considerably. The new generation peace-support operations, with political, humanitarian and military dimensions required greater co-ordination and liaison than before. This has made it essential that the relevant departments and agencies of the UN machinery function in an integrated manner. Within the Department of Peacekeeping Operations, particular effort and resources have been devoted to the development of the planning process, focusing on the operational and logistic planning and on the co-ordination of the liaison functions. The Mission Planning Service, as part of the Planning Division, is the nucleus of this process. ${ }^{43}$

\section{The Liberian peacekeeping effort}

The magnitude of peace-support operations places an extremely high premium on UN administration, organisation, co-ordination and resources. Managing multilateral inputs are especially important in respect of the clarification of the general concept of the operation; negotiations with troop contributing nations; drafting a contribution agreement between the UN and troop contributing member states concerning reimbursement for personnel and equipment; producing guidelines for troop-contributing nations to provide guidance for preparations; issuing general guidelines for the force 
commander, and organising the military component. Similarly, determining the logistic requirements, host-nation support, services to be provided by the UN, contracts concerning civilian personnel; drafting the budget and devising the development plan are matters that need to be addressed and managed. ${ }^{44}$ Multiple inputs from the UN machinery and various roleplayers are thus needed to conduct a peace-support operation as, for example, illustrated by the following basic information on UNOMIL, the UN Observer Mission in Liberia between September 1993 and September $1997 .^{45}$

\section{- Authorization}

UNOMIL was established to work alongside ECOMOG, the Economic Community of West African States 'Monitoring Group' to facilitate the Cotonou Peace Agreement of 1993, which had been signed by the conflicting parties. The mission was authorised and managed in accordance with various Security Council resolutions:

\begin{tabular}{|l|l|}
\hline $866(1993)$ of 22 September 1993 & $1020(1995)$ of 10 November 1995 \\
\hline $911(1994)$ of 21 April 1994 & $1041(1996)$ of 29 January 1996 \\
\hline $950(1994)$ of 21 October 1994 & $1059(1996)$ of 31 May 1996 \\
\hline $972(1995)$ of 13 January 1995 & $1071(1996)$ of 30 August 1996 \\
\hline $985(1995)$ of 13 April 1995 & $1083(1996)$ of 27 November 1996 \\
\hline $1001(1995)$ of 30 June 1995 & $1100(1997)$ of 27 March 1997 \\
\hline $\begin{array}{l}1014(1995) \text { of 15 September } \\
1995\end{array}$ & $1116(1997)$ of 27 June 1997 \\
\hline
\end{tabular}

The many Security Council resolutions were basically the result of persistent instability, continuing factional hostilities and an uncertain commitment of the country's political leaders to furthering the peace process. 
- Special representatives of the Secretary-General and Heads of Mission

The effectiveness of any UN operation is inextricably tied to the quality of its command-and-control arrangements in-theater and to the quality of the communication links between the functionaries in New York and the mission in the field. In this regard, the Special Representatives of the Secretary-General and Force Commanders play an important role to ensure sound communication and a clear chain of command between the UN decision-making apparatus in New York and the peace-support effort on the ground. These persons also serve as primary reporting instruments pertaining to the operational situation. In Liberia, the following persons served successively as Special Representatives of the Secretary-General:

\begin{tabular}{|l|l|}
\hline $\begin{array}{l}\text { Trevor Livingstone Gordon-Somers } \\
\text { (Jamaica) }\end{array}$ & November 1992 to November 1994 \\
\hline Anthony B. Nyakyi (Tanzania) & December 1994 to April 1997 \\
\hline Tuliameni Kalomoh (Namibia) & April to September 1997 \\
\hline
\end{tabular}

In addition, the following persons served respectively as force commanders of the mission:

\begin{tabular}{|l|l|}
\hline Maj-Gen Daniel Ishmael Opande (Kenya) & October 1993 to May 1995 \\
\hline Maj-Gen Mahmoud Talha (Egypt) & December 1995 to June 1996 \\
\hline Col David Magomere (Kenya), Acting & June to December 1996 \\
\hline Maj-Gen Sikander Shami (Pakistan) & December 1996 to September 1997 \\
\hline
\end{tabular}

\section{- Strength}

The intensely political character of contemporary peace-support tasks and frequent mandate renewals by the Security Council often involve changes to the composition of a mission. In Liberia, the strength of the UN mission had to be determined in accordance with fluctuating circumstances and comprised the following staff components: 


\begin{tabular}{|l|l|}
\hline $\begin{array}{l}\text { Authorized from 22 September 1993 to 9 } \\
\text { November 1995 }\end{array}$ & $\begin{array}{l}303 \text { military observers, 20 military medical } \\
\text { personnel and 24 military engineers }\end{array}$ \\
\hline Authorized beginning 10 November 1995 & $\begin{array}{l}160 \text { military observers supported by military } \\
\text { medical personnel, 105 international civilians } \\
\text { and 550 local civilian staff and 120 UN } \\
\text { volunteers. }\end{array}$ \\
\hline $\begin{array}{l}\text { Military strength during the electoral period } \\
\text { (July 1997) }\end{array}$ & $\begin{array}{l}92 \text { military observers, including 85 military } \\
\text { observers and 7 military support personnel }\end{array}$ \\
\hline
\end{tabular}

\section{- Financing and voluntary contributions}

At the strategic level the responsibility for planning, organising, mounting, sustaining and accounting for authorised UN operations lies with the UN functionaries in New York. Specifically, this involves the integration of all sources of supply on the one hand, and co-ordination between the various sources of support on the other. As far as UNOMIL was concerned, the financing details were as follows:

\begin{tabular}{|l|l|}
\hline Method of financing & Assessment in respect of a Special Account \\
\hline Estimated expenditure & $\begin{array}{l}\text { From inception of mission until 31 December } \\
1996: \$ 81488600 \text { net }\end{array}$ \\
\hline $\begin{array}{l}\text { Budget estimate from 1 July 1997 through 30 } \\
\text { June 1998 }\end{array}$ & \begin{tabular}{l}
$\$ 19,7$ million \\
\hline
\end{tabular} \\
\hline
\end{tabular}

The following countries made voluntary financial contributions to the UN:

\begin{tabular}{|l|l|}
\hline Denmark & $\$ 294616$ \\
\hline Egypt & $\$ 10000$ \\
\hline France & $\$ 679612$ \\
\hline Netherlands & $\$ 261584$ \\
\hline Norway & $\$ 291056$ \\
\hline United States & $\$ 22190400$ \\
\hline United Kingdom & $\begin{array}{l}\text { \$1 000 000 (for humanitarian } \\
\text { assistance) }\end{array}$ \\
\hline
\end{tabular}




\section{- Contributions of military personnel}

The independent states that are signatories to the UN Charter form the resource base of the UN. The military personnel who serve in peacesupport operations are thus provided by the member states on a voluntary basis - albeit for different reasons or motivating factors. In Liberia, the following countries helped to staff the UN mission:

\begin{tabular}{|c|c|}
\hline Austria & September 1993 to November 1994 \\
\hline Bangladesh & September 1993 to September 1997 \\
\hline Belgium & September to November 1993 \\
\hline Brazil & September to November 1993 \\
\hline China & October 1993 to August 1997 \\
\hline Congo(Brazzaville) & September 1993 to February 1994 \\
\hline Czech Republic & December 1993 to August 1997 \\
\hline Egypt & December 1993 to September 1997 \\
\hline Guinea-Bissau & September 1993 to April 1996 \\
\hline Hungary & September 1993 to January 1994 \\
\hline India & February 1994 to September 1997 \\
\hline Jordan & October 1993 to May 1996 \\
\hline Kenya & October 1993 to September 1997 \\
\hline Malaysia & September 1993 to August 1997 \\
\hline Nepal & November 1996 to September 1997 \\
\hline Netherlands & November to December 1993 \\
\hline Pakistan & September 1993 to September 1997 \\
\hline Poland & September 1993 to April 1994 \\
\hline Russian Federation & September to November 1993 \\
\hline Slovak Republic & November 1993 to October 1994 \\
\hline Sweden & September to October 1993 \\
\hline Uruguay & September 1993 to August 1997 \\
\hline
\end{tabular}

\section{Appraisal and evaluation}

In the context of the preceding, it goes without saying that peacesupport operations generally involve a magnitude of inputs to be arranged and co-ordinated by the UN machinery. Although the Secretary-General through the managerial capacities inherent in his Executive Office 
nominally directs peace-support operations, it is the Department of Peacekeeping Operations that is responsible for direction in the field. It must be realised, however, that the UN does not have a tried and tested package for peace-support operations and evaluates each situation on its merits.

Although the political will of member states is fundamentally related to perceptions of national interest, it is not, however, immutable. The perceived effectiveness of the UN itself is one of the factors that can influence it. This relates, then, to the assumption that there is a direct relationship between the effectiveness of the UN as an institution and the willingness of member states to commit political resources and capital to enhance international peace-support activities. ${ }^{46}$

Against this background, it should be noted that material and organisational factors have often undermined the military effectiveness of UN missions in the field. Accordingly, the organisation's deficiency in respect of logistic planning and support have regularly impaired the operational efficiency of UN forces. ${ }^{47}$

In Rwanda, for example, UNAMIR was faced with some of the old problems that have plagued other UN peace-support operations: troops were inadequately equipped and needed such equipment as armoured personnel carriers and even helmets and bulletproof vests. The mission relied on armoured personnel carriers in less than satisfactory condition for moving troops from one part of Rwanda to the other. During the height of the Rwandan crisis, food, medicine and other essentials ran dangerously low. Some of these problems were a result of the protracted process of obtaining financing for the mission, followed by a long procurement process for supplies and equipment. A delay in appointing a Chief Administrative Officer early in the mission's life added to these problems. In addition, troops for UNAMIR were scarce. During the first phase of the mission, the only offer of troops for logistical support came from Bangladesh. The UN had no choice but to accept, even though it was apparent that the Bangladeshi battalion did not have a sufficient resource base to provide the logistical support needed. ${ }^{48}$ 
It should furthermore be noted that as a result of unpaid contributions to peacekeeping accounts the UN has struggled to settle a \$1 billion debt in $1996 / 97$ owed to 81 member states which provided troops and equipment. At the end of 1996, the UN owed Pakistan \$67 million and India \$58 million for their contributions to peace-support operations. Understandably, member states have become sensitive about high costs and are more reluctant to participate in peace-support operations in the light of a UN budget deficit. ${ }^{49}$

The financial restraints under which the UN Department of Peacekeeping Operations has had to operate in recent years, both because of the increase in the number of intra-state conflicts and the failure of states to make their payments, have inhibited effective action on the part of the world body. On a positive note, it would seem that progress has been made recently towards resolution of the latter problem ${ }^{50}$ and it is hoped that a satisfactory outcome will emerge in future. In the final analysis, it must be realised that the real cost of peace-support operations must ultimately be measured against the cost of the alternative - war.

What is significant in view of the above is the point that the UN now seems prepared to hand over responsibility for peace and security to willing regional organisations and alliances. In the case of UNOMIL, the more robust 'peacekeeping' was done by ECOMOG, while the UN mission was deployed to observe the 'peace-keepers' as well as the belligerents. Moreover, the Security Council has stretched the UN Charter to its limits as regards peacekeeping in the Central African Republic, when the InterAfrican Mission to Monitor the Implementation of the Bangui Agreement (MISAB) was mandated on 6 August 1997 to take responsibility for the maintenance of peace and security. As far as the UN was concerned, UN member states were not assessed for any portion of the mission costs which had to be borne by the participating countries. ${ }^{51}$ 


\section{FUTURE UN INVOLVEMENT IN AFRICAN PEACEKEEPING}

For the UN there is no higher goal, no deeper commitment and no greater ambition than preventing armed conflict. The UN is clearly aware of the fact that the international community's perception of peace-support operations has been greatly shaped by the UN's experience in African countries.

African countries have begun to make economic and political progress in recent years, but in some parts of the continent progress remains threatened or impeded by conflict. The question is: Where is African peacekeeping heading? If the report of Mr Kofi Annan, Secretary-General of the UN, on The Causes of Conflict and the Promotion of Durable Peace and Sustainable Development in Africa is to be taken as a pointer towards the future of UN involvement in African peacekeeping requirements, it would seem that the organisation is eager to add momentum to Africa's renewed quest for peace and greater prosperity. Three aspects are of special relevance:

- The Secretary-General holds the view that under the right conditions, UN peace-support operations can make the difference between peace and war in Africa. However, his view includes the realisation that UN peacekeeping will not always be the best answer to every problem in Africa or elsewhere. Yet, where opportunities in Africa arise, the international community should provide its support, demonstrating its commitment to peace in a tangible way.

- Most important is the Secretary-General's view that the provision of support for regional and sub-regional initiatives is regarded as both necessary and desirable. It is necessary because the UN lacks the capacity, resources and expertise to address all problems that may arise in Africa. It is also desirable because, wherever possible, the international community should strive to complement rather than 
supplant African efforts to resolve Africa's problems. By the same token, reinforcing the capacity of African countries to operate in peace-support operations is a key priority, whether those operations take place in the framework of a UN mission or are conducted by a regional organisation or group of states in accordance with Security Council authority. The Secretary-General recognises that, in recent years, there have been a number of new African initiatives to resolve disputes that have long plagued particular areas or to tackle new conflicts before they can expand and escalate beyond control. The activities of ECOMOG in Liberia are especially regarded as an example of co-operation between the UN and a sub-regional organisation that might be applicable to future situations.

- The view is also held that wide disparities in the international community's commitment to preventing or containing conflicts in different regions impede the ability of the UN to promote a stable and just international order anywhere. Member states must therefore be engaged in terms of political will and practical resources if the viability of the UN and the principle for which it stands are to be safeguarded, let alone advanced.

In addition, summoning the necessary political will is at stake. According to Khopi Annan, this relates to two aspects:

- Firstly, that Africa must demonstrate the will to rely upon political rather than military responses to problems. African countries must likewise summon the will to take good governance seriously, ensuring human rights and the rule of law, strengthening democratisation and promoting transparency in public administration.

- Secondly, political will is also needed from the international community. Where the international community is committed to making a difference, it has proved that significant and rapid transformation can be achieved. 
It is furthermore realised that the credibility of the UN in Africa to a great extent depends upon the international community's willingness to act and to explore new means of advancing the objectives of peace and security on the continent. It is therefore important for the organisation to be guided by lessons from its experience in Africa in order to support the continent in the search for economic and political progress. ${ }^{52}$

\section{CONCLUSION}

It is clear from the above that each $\mathrm{UN}$ peace-support operation places an extremely high premium on UN administration, organisation, coordination and resources, and that a multiplicity of inputs by various roleplayers is needed. Moreover, the new generation peace-support operations, with political, humanitarian and military dimensions require greater coordination and liaison than before. This has made it essential that the relevant departments and agencies of the UN machinery function in an integrated manner. This is also of special importance, as it would appear that there is a relationship between the effectiveness of the UN as an institution and the willingness of member states to commit resources and capital to enhance international peace-support activities.

It is furthermore clear that participation in peace-support operations require significant commitments on the part of participating states, specifically the willingness to accept financial costs and fatalities in the interest of promoting international and regional stability. High fatalities can therefore have long term effects on a nation's willingness to participate in future operations or even operations in a certain part of the world. In fact, with the rise in fatalities sustained by UN missions in the 1990s worldwide, a number of countries have increasingly become reluctant to commit their forces. For any democratic government it is extremely difficult to justify fatalities in peace-support operations where clear and compelling interests cannot be identified. In addition, the costs of such operations and the massive logistic commitment for long distance operations - as in the case of 
African conflicts - are key factors in the decision-making processes of responsible governments.

Africa is a continent that is steeped in conflict, the sources of which are both diverse and endemic. Therefore, African peace-support operations seem to be an even greater challenge than those in most other parts of the world are. Past and recent experiences in the conducting of African peacesupport operations have indicated that such operations present serious challenges and a hostile operational environment to forces assuming a peace-support role. It is accordingly a truism that the undertaking of peacesupport operations in Africa is by no means a simple and easy task.

The difficulties and perils associated with peacekeeping in Somalia, Rwanda, Mozambique and Angola have already resulted in an increasing reluctance on the part of the major powers and the traditional troopcontributing nations to deploy their troops on African soil. As a result of this, the American, French and British proposals with regard to African peacekeeping requirements are currently oriented to pursue an African approach in resolving African conflicts.

It must furthermore be realised that the continent's physical remoteness from the core of Western interests does not encourage a proper focus on the challenges or the means to address them. Accordingly, it can be concluded that the real impact of the post-Cold War era is that the burden of resolving African conflicts rests more and more on Africans themselves. African countries and organisations are therefore compelled to take measures and develop strategies to address the peacekeeping requirements on the continent. This would imply that the practice of deploying regional and sub-regional peace forces might become of increasing relevance and significance in the African context. However, poverty in a large number of countries reduces their ability to deal effectively with intra-state conflicts. As a result, the UN and the Western world are likely to be saddled with at least the material cost of UN peace-support operations on the African continent in the foreseeable future.

\section{REFERENCES}


Annan, K, The Causes of Conflict and the Promotion of Durable Peace and Sustainable Development in Africa: Report of the Secretary-General, New York, 1998.

UN, Charter of the United Nations, San Francisco, June 26, 1945.

Ibid.

UN (Department of Public Information), Internet site http://www.un.org/Depts/DPKO/faq.htm, 1998.

Boutros-Ghali, B, An Agenda for Peace: Preventive Diplomacy, Peacemaking and Peacekeeping. United Nations, New York.

UN (Department of Political Affairs), Internet site http://www.un.org/Depts/dpa/docs/peacemak.htm, 1997.

Cilliers, J and Malan, M, "From Destabilization to Peacekeeping in Southern Africa: The Potential of Southern Africa", Africa Insight, vol 26, no 4, 1996, p 342-343.

Rifkind, M, "Peacekeeping or Peacemaking? Implications and Prospects", The Rusi Journal, April 1993, pp 2-3.

Anon., "The Clinton Administration's Policy on Reforming Multilateral Peace Operations (Presidential Directive 25, May 1994)", Small Wars and Insurgencies (special issue), vol 7, no 1, Spring 1996, pp 5-6.

The notion "UN peace-support operations" as used in this document is referred to by the UN Department of Public Information as "UN peacekeeping operations". Sources sometimes differ on the number of "UN peacekeeping operations" as observer missions are arbitrarily included in or excluded from this notion. The information presented in this document is taken from the UN Department of Public Information.

UN (Department of Public Information), Internet site http://www.un.org/Depts/DPKO/p_miss.htm, 1998.

All data are obtained from unofficial UN sources and omissions or errors may occur.

UN (Department of Public Information), Internet site http://www.un.org/Depts/DPKO/Missions/ unavemi.htm, 1998.

UN (Department of Public Information), Internet site http://www.un.org/Depts/DPKO/Missions /unavemii.htm, 1998.

UN (Department of Public Information), Internet site http://www.un.org/Depts/DPKO/Missions /unavem f.htm, 1998.

UN (Department of Public Information), Internet site http://www.un.org/Depts/DPKO/Missions /unasog.htm, 1998.

UN (Department of Public Information), Internet site http://www.un.org/Depts/DPKO/Missions /unomir_p.htm, 1998.

UN (Department of Public Information), Internet site http://www.un.org/Depts/DPKO/Missions /unomil_p.htm, 1998.

UN (Department of Public Information), Internet site
http://www.un.org/Depts/DPKO/Missions /unomur.htm, 1998.

UN (Department of Public Information), Internet site http://www.un.org/Depts/DPKO/Missions 
/unoc.htm, 1998.

UN (Department of Public Information), Internet site http://www.un.org/Depts/DPKO/Missions /untag.htm, 1998.

UN (Department of Public http://www.un.org/Depts/DPKO/Missions /unosomi.htm, 1998.

UN (Department http://www.un.org/Depts/DPKO/Missions /unosom2p.htm, 1998.

UN (Department http://www.un.org/Depts/DPKO/Missions /unomoz_p.htm, 1998. http://www.un.org/Depts/DPKO/Missions /onuca.htm, 1998.

UN (Department of Public http://www.un.org/Depts/DPKO/Missions /onmih.htm, 1998.

UN (Department http://www.un.org/Depts/DPKO/Missions /untac.htm, 1998.

UN (Department of Public http://www.un.org/Depts/DPKO/Missions /uncro.htm, 1998.

UN (Department of Public http://www.un.org/Depts/DPKO/Missions /unprof_p.htm, 1998.

This statement does not take into consideration or relate to figures of fatalities in respect of long-standing UN observer missions in the Golan Heights, Beirut and Sinai. UN (Department of Public
http://www.un.org/Depts/DPKO/Missions /unefi.htm, 1998. http://www.un.org/Depts/DPKO/Missions /unefii.htm, 1998.

(Department of Public http://www.un.org/Depts/DPKO/Missions /uniimog.htm, 1998.

UN (Department of Public Information), Internet site http://www.un.org/Depts/DPKO/Missions /unefii.htm, op cit.

UN (Department of Public Information), Internet site http://www.un.org/Depts/DPKO/faq.htm, op cit.

Shelton, G, "Preventive Diplomacy and Peacekeeping", African Security Review, vol 6, no 5 , pp 1; 7-9.

Cilliers, J and Malan, M, op cit, p 339. 
Malan, M, "Treading Firmly on the Layered Response Ladder: From Peace Enforcement to Conflict Termination Operations in Africa", African Security Review, vol 6, no 5, 1997, p 46.

Bagger, H, "European Security in the 21st Century - New Tasks for the Bundeswehr", Speech by the Chief of Staff of the German Armed Forces at the SA Defence College, Pretoria, 23 February 1998.

Steyn, P, "South Africa and Peace-support Operations: Limitations, Options and Challenges", Paper presented at a Conference on Contemporary Peace-support Operations, 5 November 1997, Pretoria, p 6.

Whitelaw, K, "A Mission for Africa: The West Makes Peacekeeping a Do-it-yourself Project”, U.S. News and World Report, September 1997, p 35.

Berdal, M R, "Whither UN Peacekeeping", Adelphi Paper, no 281, October 1993, p 33.

UN (Department of Peacekeeping Operations), Internet site http://www.un.org/Depts/DPKO/rapid/ mp.htm, 1998.

Voetman, P, "The Structure, Planning and Execution of UN Peace Operations", in Malan, M (ed.), Conflict Management, Peacekeeping and Peace-Building, ISS Monograph Series, no 10, April 1997, p 32.

UN (Department of Public Information), Internet site http://www.un.org/Depts/DPKO/Missions /unomil_p.htm, op cit.

Berdal, op cit, p 5 .

Ibid, p 26.

UN (Department of Peacekeeping Operations), Internet site http://www.un.org/Depts/DPKO/lessons /rwandisc.htm, 1998.

Anon., "Briefing: Debts Undermine UN Peacekeeping", Jane's Defence Weekly, vol 27, no 1, 1997, p 19.

Steyn, op cit, p 7.

Malan, M, Peacekeeping in Africa: Trends and Responses. Paper presented at a Seminar on Building African Peacekeeping Capacity, 20 May 1998, Midrand, p 4.

Annan, K, op cit. 